NOTE

\title{
Use of prawn blood agar hemolysis to screen for bacteria pathogenic to cultured tiger prawns Penaeus monodon
}

\author{
Chin-I Chang, Wen-Yu Liu*, Chung-Zen Shyu
}

Department of Aquaculture, Taiwan Fisheries Research Institute, 199 Hou-Ih Rd, Keelung 202, Taiwan

\begin{abstract}
A newly developed prawn blood agar consisting of $1 \mathrm{ml}$ of tiger prawn hemolymph in medium containing 200 ppm Rose Bengal was used to determine the hemolytic activity of 35 isolates of bacteria obtained from cultured tiger prawns Penaeus monodon and their rearing water. For comparison, the hemolytic activity of these isolates was also determined in sheep blood agar. Nine isolates $(25.7 \%$ of total) showed different hemolytic reactions on prawn blood agar and sheep blood agar. From the 35 isolates, 8 with various hemolytic characteristics were selected and the relationship between the type of hemolytic activity and pathogenicity was determined and compared. Four isolates that showed hemolytic activity in prawn blood agar caused high mortality to cultured tiger prawns. By contrast, a significantly lower mortality rate was observed for tiger prawns injected with 4 isolates that did not exhibit hemolytic activity on prawn blood agar. Results further showed that mortality did not correlate with hemolytic activity determined using sheep blood agar. Prawn blood agar containing $P$. monodon hemocytes was faster and more accurate for determining prawn hemolytic activity of bacterial isolates.
\end{abstract}

KEY WORDS: Prawn blood agar $\cdot$ Hemolytic bacteria $\cdot$ Pathogenicity $\cdot$ Penaeus monodon

Resale or republication not permitted without written consent of the publisher

Bacterial disease is one of the most serious problems in the culture of the tiger prawn Penaeus monodon (Chen et al. 1992). A major symptom of bacterial infection in tiger prawns is serious hepatopancreatic necrosis. However, both pathogenic and non-pathogenic bacteria are often found in the prawn hepatopancreas (Ruangpan \& Kitao 1991, Chang et al. 1996a) and it has been suggested that their hemolytic activity may be correlated to their pathogenicity, since factors such as adhesion and invasion (Ruangpan et al. 1994) have been excluded. Although there is still much disagreement about the relationship between hemolysis and pathogenicity (Inamura et al. 1984, Chung \& Kou 1985,

${ }^{*}$ Corresponding author. E-mail: wyliu@mail.tfrin.gov.tw
Kodama et al. 1985), hemocytolytic assay is still commonly used to differentiate among suspected pathogens (Ullah \& Arai 1983, Chen et al. 1995, Lee et al. 1995).

Conventional methods of hemocytolytic assay are carried out either using commercial sheep blood agar (Collins \& Lyne 1984) or by direct observation of hemocytes under a microscope (Lee et al. 1995). The latter method requires staining of the hemocytes followed by continuous observation and is not suitable for efficient screening of large numbers of bacterial isolates from tiger prawns and their culture environment because it is labor-intensive and time-consuming. Until recently, many researchers used sheep blood agar to study bacterial diseases in prawns (Song et al. 1993). Although prawn blood agar plates might be considered as an alternative, hemolytic clear zones would be difficult to visualize because prawn hemocytes are colorless. This is unfortunate because the mammalian non-nucleated blood cell with hemoglobin is fundamentally different from the non-pigmented, nucleated prawn hemocyte and so it should not be assumed that hemolytic activity observed in tests using sheep blood agar would indicate hemolytic activity for prawn hemocytes.

In the present study, the hemolytic capability of bacteria isolated from cultured tiger prawns and their rearing water were screened using a newly developed prawn blood agar (Chang et al. 1996b) with which hemolytic features could be easily interpreted by the naked eye. Differences in hemolytic activity of aquatic bacteria on prawn blood agar and sheep blood agar were compared. Based on challenge experiments, the correlation between the type of hemolytic activity and bacterial pathogenicity was examined.

Materials and methods. Using a sterile needle (26G $\times 1 / 2^{\prime \prime}$ ) and $1 \mathrm{ml}$ syringe, hemolymph was drawn between the first and second pleopods from tiger prawns previously surface-disinfected with $70 \%$ ethanol. The 
syringe was rinsed inside with citrate-EDTA buffer containing $0.1 \mathrm{M}$ glucose, $30 \mathrm{mM}$ trisodium citrate, $26 \mathrm{mM}$ citric acid, and $10 \mathrm{mM}$ EDTA dissolved in 20 ppt seawater. The $\mathrm{pH}$ of the buffer solution was adjusted to 4.6 and sterilized at $121^{\circ} \mathrm{C}$ for $15 \mathrm{~min}$ (Soderhall \& Smith 1983). The hemolymph (1 ml) was immediately transferred into a sterilized tube containing $0.2 \mathrm{ml}$ citrate-EDTA buffer and stained by addition of $133 \mu \mathrm{l} \mathrm{3 \%}(\mathrm{w} / \mathrm{v})$ Rose Bengal (dissolved in citrateEDTA buffer) with gentle rotation to achieve complete mixing. The basal agar medium comprised $10 \mathrm{~g}$ Bacto peptone, $5 \mathrm{~g}$ sodium chloride and $15 \mathrm{~g}$ Bacto agar dissolved in $1000 \mathrm{ml}$ water, adjusted to $\mathrm{pH} 6.8$, autoclaved for $15 \mathrm{~min}$ at $15 \mathrm{psi}$ and $121^{\circ} \mathrm{C}$, and cooled to $45-50^{\circ} \mathrm{C}$ in a water-bath. Aseptically, $1 \mathrm{ml}$ of the stained hemolymph preparation was added to $15 \mathrm{ml}$ of this prepared basal medium followed by gentle mixing and pouring into petri dishes. The other blood agar medium used was commercial sheep blood agar (Difco).

Twelve reference strains were obtained from the Culture Collection \& Research Center, Hsinchu, Taiwan. Twenty-three test isolates were also obtained from the hepatopancreas of cultured tiger prawns and their rearing water. To accomplish this, the hepatopancreases of cultured tiger prawns were removed and homogenized with sterilized instruments. Samples from rearing pond water were collected aseptically $10 \mathrm{~cm}$ above the bottom mud. Both sample types were then diluted serially 10-fold and $0.1 \mathrm{ml}$ of diluent was spread onto plates of Marine agar 2216 (Difco). All plates were incubated at $23^{\circ} \mathrm{C}$ for $7 \mathrm{~d}$. Isolates were selected randomly and purified by subculture of single colonies 3 times. The selected isolates were then identified following the Bergey's manual (Krieg \& Holt 1984) and using the Biolog ${ }^{\circledR}$ commercial system (MicroStation System).

Bacteria were inoculated onto the 2 types of blood agar and incubated at $23^{\circ} \mathrm{C}$ for 3 to $7 \mathrm{~d}$. A positive indication of hemolysis was the formation of a transparent zone around the inoculated colonies. Two pieces of $4 \mathrm{~mm}^{2}$ blood agar were taken from the transparent and stained zones to confirm hemolysis by observation with a compound microscope.

Tiger prawn post-larvae 15 (PL15) from a hatchery at I-Lan in Taiwan were reared in our laboratory until they reached approximately $10 \mathrm{~g}$ before healthy individuals were selected for use in the challenge experiments. Eight isolates selected on the basis of hemolytic activity profile were employed for the challenge experiments. Two isolates showed positive hemolytic activity both in prawn and sheep blood agar, 2 were positive in prawn blood agar only, 2 were positive in sheep blood agar only and 2 had no hemolytic ability in either blood agar. Bacterial suspensions were adjusted to a concentration of $10^{7} \mathrm{CFU} \mathrm{ml} \mathrm{m}^{-1}$ and injected intramuscularly into tiger prawns at a dose of $1 \% \mathrm{v} / \mathrm{body}$ wt. Each isolate was used to challenge 12 tiger prawns in duplicate trials. After challenge, prawns of each batch were reared in independent tanks for $2 \mathrm{wk}$. The number of dead prawns was recorded daily. Survival percentages were estimated by the following equation:

Survival rate $(\%)=\frac{\text { No. of surviving prawns }}{\text { Total no. of prawns }-A} \times 100 \%$

where $A$ was the number of dead prawns on the first day after challenge, since this mortality could be considered due to handling stress.

The hepatopancreases from dead shrimp were excised and homogenized for bacterial isolation by serial dilution plating as previously described, no longer than $1 \mathrm{~h}$ after death. Ten colonies were randomly isolated from the dilution plates for each sample. If there were more than 5 colonies the same as the isolate that was injected in the challenge experiment, we considered that the isolate had been re-isolated from infected tissues. This re-isolation procedure was not used if the time the prawn died could not be determined. After $2 \mathrm{wk}$, all the test prawns were sacrificed to determine the re-isolation ratio for the different isolates used in the challenge experiments.

Results. Rose Bengal reagent specifically stains prawn hemocytes but not the other proteins of the hemolymph (Fig. 1a). Thus, prawn blood agar appeared rose red because of well distributed, stained hemocytes. When the hemocytes were destroyed by hemolytic bacteria, a clear zone appeared around the colonies and could easily be recognized by the naked eye (Fig. 1b). Microscopic observation revealed intact dyed hemocytes in prawn blood agar away from hemolytic zone around bacterial colonies (Fig. 1c), while only hemocyte debris was seen adjacent to the colonies (Fig. 1d).

The hemolytic results of a total 35 aquatic bacterial isolates inoculated on both prawn blood agar and sheep blood agar are shown in Table 1 . There were 9 isolates $(25.7 \%$ of total) that exhibited differential hemolytic reactions on the 2 blood agars. The onset of hemolysis on the 2 blood media also differed in that it occurred faster on prawn blood agar than on sheep blood agar. Specifically, 35 isolates gave results on prawn blood agar by the 3rd day of culture, while 12 isolates inoculated on sheep blood agar did not show hemolytic activity until the 7 th day of culture (Table 1).

Eight isolates selected from Table 1 were employed in the challenge experiments. They included 30 and 33 which showed hemolysis on both prawn and sheep blood agar, 3 and 28 which showed hemolysis on prawn blood agar only, 6 and 23 which showed hemolysis on sheep blood agar only and 24 and 27 which showed no hemolysis on either blood agar. Challenge 
results (Table 2) revealed that isolates with hemolytic activity on prawn blood agar generally caused significantly higher tiger prawn mortality $(\mathrm{p}<0.05)$ than those without such activity. Specifically, the survival rates of prawns challenged with hemolytic isolates 3 , 28,30 , and 33 were $25 \%, 17 \%, 0 \%$, and $17 \%$, respectively, while those for test prawns challenged with non-hemolytic isolates 23, 24, and 27 were $100 \%$, $92 \%$, and $83 \%$, respectively. The exception was Vibrio damsela CCRC12906 (isolate no. 6), which showed negative hemolysis on prawn blood agar but caused $46 \%$ mortality. This was higher mortality $(p<0.05)$ than other isolates without hemolysis on prawn blood agar. No significant relationship was found between mortality of challenged prawns and bacterial hemolytic activity observed using sheep blood agar.
Discussion. The results of this study showed that a newly developed prawn blood agar (Chang et al. $1996 b)$ is better than sheep blood agar for discriminating potential bacterial pathogens derived from cultured tiger prawns and their rearing environment. The method can be used for rapid and more effective largescale screening of potential shrimp bacterial pathogens from the aquatic environment. The results are more relevant to shrimp than those obtained using more traditional mammalian blood agar.

Although hemolytic activity is considered one of the pathogenic features of bacteria, it may not always be useful in determining pathogenicity. For example, both hemolytic and non-hemolytic strains of Streptococcus (e.g., S. pyogenes, and S. mutans, respectively) are important human pathogens (Michael et al. 1988). In
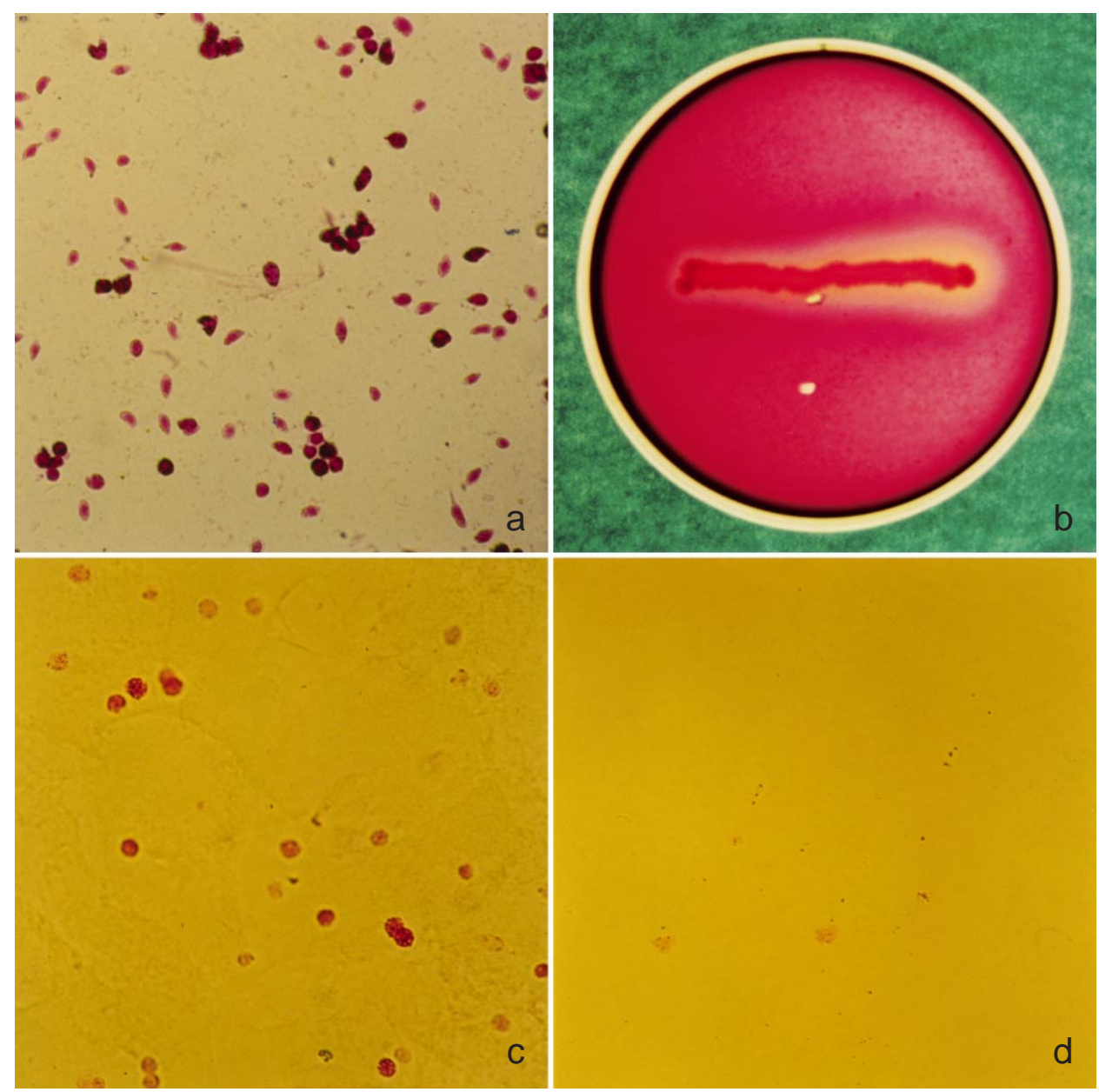

Fig. 1. (a) Hemocytes $(400 \times)$ of tiger prawn stained with Rose Bengal agent $(0.3 \% \mathrm{w} / \mathrm{v}$ final conc.) before addition to basal medium. Rose Bengal stained the hemocytes only; no other proteins in the hemolymph were stained. (b) On prawn blood agar, the hemolytic clear zone surrounding the inoculated bacterial colonies is clearly visible by the naked eye. (c) Intact dyed hemocytes in a block of prawn blood agar removed from an area away from the clear zone and observed under a microscope at 400×. (d) Weakly stained debris of lysed hemocytes in a block of prawn blood removed from the clear zone (cuts visible in Fig. 1b) 
Table 1. Results of hemolytic tests of 35 bacterial isolates on prawn and sheep blood agar at $23^{\circ} \mathrm{C}$ at 3 and $7 \mathrm{~d}$. CCRC: Culture Collection and Research Center in Taiwan; +: hemolysis positive, -: hemolysis negative

\begin{tabular}{|c|c|c|c|c|}
\hline No. & Species & Source & $\begin{array}{c}\text { Hemolysi } \\
\text { Prawn }\end{array}$ & $\begin{array}{l}\mathrm{s}(3 / 7 \mathrm{~d}) \\
\text { Sheep }\end{array}$ \\
\hline 1 & Aeromonas hydrophila & CCRC 11032 & $+/+$ & $+/+$ \\
\hline 2 & Escherichia coli & CCRC 51731 & $-1-$ & $-1-$ \\
\hline 3 & Vibrio alginolyticus & CCRC 12829 & $+/+$ & $-/-$ \\
\hline 4 & V. anguillarum & CCRC 12908 & $+/+$ & $+/+$ \\
\hline 5 & V. carchariae & CCRC 14141 & $+/+$ & \\
\hline 6 & V. damsela & CCRC 12906 & $-1-$ & $+/+$ \\
\hline 7 & V. harveyi & CCRC 12907 & $+/+$ & $+/+$ \\
\hline 8 & V. mimicus & CCRC 14161 & $+/+$ & $+/+$ \\
\hline 9 & V. ordalii & CCRC 13866 & $-1-$ & $-/+$ \\
\hline 10 & V. parahaemolyticus & CCRC 12865 & $+/+$ & $-/+$ \\
\hline 11 & V. salmonicida & CCRC 12844 & $-/-$ & $-1+$ \\
\hline 12 & $V$. vulnificus & CCRC 12905 & $-/-$ & $-/+$ \\
\hline 13 & Acinetobacter genospecies & Rearing water & $-1-$ & $-1-$ \\
\hline 14 & Alcaligenes latus & Rearing water & $-/-$ & $-1-$ \\
\hline 15 & A. latus & Rearing water & $+/+$ & $+/+$ \\
\hline 16 & Flavobacterium gleum & Rearing water & $+/+$ & $-1+$ \\
\hline 17 & Serratia liquefaciens & Rearing water & $-1-$ & $-/-$ \\
\hline 18 & Shewanella putrefaciens $C$ & Rearing water & $+/+$ & $+/+$ \\
\hline 19 & $V$. anguillarum & Rearing water & $+/+$ & $-1+$ \\
\hline 20 & V. parahaemolyticus & Rearing water & $+/+$ & $+/+$ \\
\hline 21 & Acinetobacter radioresistens & Rearing water & $-1-$ & $-1-$ \\
\hline 22 & Moraxella sp. & Rearing water & $-1-$ & $-1+$ \\
\hline 23 & Moraxella sp. & Rearing water & $-1-$ & $-1+$ \\
\hline 24 & V. harveyi & Rearing water & $-1-$ & $-1+$ \\
\hline 25 & Xanthomonas oryzae & Rearing water & $-1-$ & $-1-$ \\
\hline 26 & A. hydrophila & Hepatopancreas of prawn & $+/+$ & $+/+$ \\
\hline 27 & Aeromonas sobria & Hepatopancreas of prawn & $-1-$ & $-/-$ \\
\hline 28 & V. alginolyticus & Hepatopancreas of prawn & $+/+$ & $-1-$ \\
\hline 29 & $V$. mimicus & Hepatopancreas of prawn & $+/+$ & $+/+$ \\
\hline 30 & $V \cdot$ parahaemolyticus & Hepatopancreas of prawn & $+/+$ & $-/+$ \\
\hline 31 & S. putrefaciens $C$ & Hepatopancreas of prawn & $+/+$ & $+/+$ \\
\hline 32 & $V$. anguillarum & Hepatopancreas of prawn & $+/+$ & $+/+$ \\
\hline 33 & V. anguillarum & Hepatopancreas of prawn & $+/+$ & $+/+$ \\
\hline 34 & V. parahaemolyticus & Hepatopancreas of prawn & $+/+$ & $-/+$ \\
\hline 35 & V. parahaemolyticus & Hepatopancreas of prawn & $+/+$ & $+/+$ \\
\hline
\end{tabular}

tured tiger prawns. On the other hand, all the isolates we found to be hemolytic for prawn blood agar caused high mortality and could be re-isolated from challenged tiger prawns.

The Rose Bengal staining method is the most practical and widely used method for obtaining quantitative data on live benthic foraminifera (Mackensen \& Douglas 1989, Bernhard 1992). Based on the high affinity of Rose Bengal to protoplasm, the authors modified the staining method such that the agent stained nothing else except hemocytes in prawn hemolymph. In some instances, it is possible that hemolymph drawn from shrimp to prepare prawn blood agar may already be contaminated with bacteria (Lightner 1988) and this might affect the sterility of the prepared prawn blood agar. However, Rose Bengal is an effective anti-bacterial agent and preparation of the hemocytes at a high concentration $(0.3 \% \mathrm{w} / \mathrm{v})$ in an initial step generally appeared to solve this problem in our experience. In addition, dilution to 200 ppm by mixing with the basal medium appeared to result in a lowered concentration, insufficient to interfere with growth of tested isolates. The hemocytolytic assay method used in this study may also be applicable for other animal species that have unpigmented or colorless blood. addition to hemolysins, bacterial pathogenic factors such as enterotoxins, proteases, and hemagglutinins have also been reported for aquatic organisms (Inamura et al.1984). Song et al. (1993) isolated 12 Vibrio damsela strains from Penaeus monodon which were demonstrated as pathogenic for the tiger prawn and which possessed hemolytic ability for erythrocytes of sheep. In our study, the strain $V$. damsela CCRC12906 (originally isolated from human feces) was also hemolytic for sheep blood cells but not for prawn hemocytes. Nevertheless, it caused higher mortality in test prawns than other isolates that did not lyse prawn hemocytes. Thus, it is possible that non-hemolytic bacteria may still be pathogenic and cause disease in cul-
Table 2. Penaeus monodon. Survival rate of tiger prawns 2 wk after challenge with selected bacterial isolates. PBA: tiger prawn blood agar; SBA: sheep blood agar. Values within a column not sharing the same superscripts are significantly different $(\mathrm{p}<0.05)$

\begin{tabular}{|lllllc|}
\hline $\begin{array}{l}\text { Isolate Species } \\
\text { no. }\end{array}$ & $\begin{array}{r}\text { Hemolysis } \\
\text { PBA }\end{array}$ & $\begin{array}{c}\text { SBA } \\
\text { rate (\%) }\end{array}$ & $\begin{array}{c}\text { Re-isolation } \\
\text { rate (\%) }\end{array}$ \\
\hline 3 & Vibrio alginolyticus & + & - & $25^{\mathrm{a}}$ & 79 \\
6 & V. damsela & - & + & $54^{\mathrm{b}}$ & 58 \\
23 & Moraxella sp. & - & + & $100^{\mathrm{c}}$ & 4 \\
24 & V. harveyi & - & - & $92^{\mathrm{c}}$ & 17 \\
27 & Aeromonas sobria & - & - & $83^{\mathrm{c}}$ & 8 \\
28 & V. alginolyticus & + & - & $17^{\mathrm{a}}$ & 91 \\
30 & V. parahaemolytics & + & + & $0^{\mathrm{a}}$ & 100 \\
33 & V. anguillarum & + & + & $17^{\mathrm{a}}$ & 87 \\
\hline
\end{tabular}




\section{LITERATURE CITED}

Bernhard JM (1992) Benthic foraminiferal distribution and biomass related to pore-water oxygen content: central California continental slope and rise. Deep-Sea Res 39: 585-605

Chang, CI, Chung HY, Kou GH (1996a) Numerical taxonomy of bacteria isolated from the hepatopancreas of giant tiger prawn Penaeus monodon, fleshy prawn $P$. chinensis and their culture water. J Fish Soc Taiwan 23:117-136

Chang CI, Lee WC, Shyu CZ, Liao IC (1996b) The development of shrimp blood agar for testing the hemolysis of shrimp's haemocyte by bacteria. Chinese J Microbiol Immunol 29:232-239

Chen JD, Lai SY, Huang SL (1995) Cloning of the hemolysin gene from Edwardseilla tarda. J Fish Soc Taiwan 22: 267-277

Chen SN, Huang SL, Kou GH (1992) Studies on the epizootiology and pathogenicity of bacterial infections in cultured giant tiger prawns, Penaeus monodon, in Taiwan. In: Fulks W, Main KL (eds) Diseases of cultured penaeid shrimp in Asia and the United States: proceedings of a workshop in Honolulu, Hawaii. The Oceanic Institute, Honolulu, Hawaii, p 195-205

Chung HY, Kou GH (1985) Characteristics of non-hemolytic streptococci isolated from infected captive bullfrog (Rana catesbeiana). COA Fish Ser 4:9-21

Collins CH, Lyne PM (1984) Microbiological methods, 5th edn. Butterworth Ltd, London, p 56-88

Inamura H, Muroga K, Nakai T (1984) Toxicity of extracellular products of Vibrio anguillarum. Fish Pathol 19:89-96

Kodama H, Moustofa M, Mikami T, Izawa H (1985) Partial purification of extracellular substance of Vibrio anguil-

Editorial responsibility: Timothy Flegel,

Bangkok, Thailand larum toxigenic for rainbow trout and mouse. Fish Pathol 20:173-179

Krieg NR, Holt JG (1984) Bergey's manual of systematic bacteriology. Williams \& Wilkins, Baltimore

Lee KK, Chen FR, Liu PC (1995) A haemocytolytic assay for tiger prawn, Penaeus monodon. Fish Shellfish Immunol 5: 385-387

Lightner DV (1988) Vibrio disease. In: Sindermann CJ, Lightner DV (eds) Disease diagnosis and control in North American marine aquaculture, 2nd edn. Elsevier, New York, p 42-47

Mackensen A, Douglas RG (1989) Down-core distribution of live and dead deep-water benthic foraminifera in box cores from the Weddell Sea and the California continental borderland. Deep-Sea Res 36:879-900

Michael JP, Chan ECS, Krieg NR (1988) Microbiology, 2nd edn. McGraw-Hill, New York, p 287-288

Ruangpan L, Kitao T (1991) Vibrio bacteria isolated from black tiger shrimp, Penaeus monodon Fabricius. J Fish Dis 14:383-388

Ruangpan L, Tabkaew R, Sangrungruang K (1994) Bacterial flora of intensive cultured black tiger shrimp, Penaeus monodon. Suisanzoshoku 42:485-490

Soderhall K, Smith VJ (1983) Separation of the haemocyte populations of Carcinus maenas and other marine decapods, and prophenoloxidase distribution. Dev Comp Immunol 7:229-239

Song YL, Cheng W, Wang CH (1993) Isolation and characterization of Vibrio damsela infectious for cultured shrimp in Taiwan. J Invertebr Pathol 61:24-31

Ullah A, Arai T (1983) Pathological activities of the naturally occurring strains of Edwardseilla tarda. Fish Pathol 18: $65-70$

Submitted: May 16, 2000; Accepted: August 7, 2000

Proofs received from author(s): October 10, 2000 